\title{
Employing A Tax Practitioner: A Different Perspective
}

Vassilios N. Gargalas, Herbert H. Lehman College, USA

\begin{abstract}
In this paper, we analyze the value of services rendered by tax practitioners, demonstrating that the conventional single-period solution may be inconsistent with their role. We contend that the value of these services stems from tax practitioners' knowledge of the tax code and not from the signal they convey to tax authorities when they sign the returns. We take the position that taxpayers' actions may not convey a signal to the tax enforcement agent, thereby enabling the latter to set different detection rates for different taxpayers. If taxpayers' actions were to convey a signal, the solution would not be sustainable, since it would eventually lead to a self-revealing "corner solution," in which all taxpayers would take the same action.

In a single-period framework, the taxpayer's decision to hire a practitioner is dependent upon two variables: the practitioners' fee, which is known to the tax enforcement agent, and taxpayers' risk attitude. The tax enforcement agent can infer the latter if the taxpayers use practitioners who sign the tax returns. If taxpayers use practitioners' services, we are able to derive the same exact solution irrespective of whether or not practitioners sign the returns. Thus, we suspect that the value of these services does not stem from the fact that the returns are signed.
\end{abstract}

Keywords: Tax practitioner, Tax payer, Corner solution, Enforcement agent, IRS, Detection rate, tax code

\section{SYNOPSIS AND INTRODUCTION}

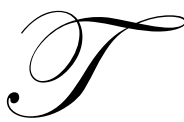

he role of the tax practitioner in tax compliance has been the subject of a substantial amount of research in recent years (for example, Alm (1988), Shavell(1988), Beck and Jung (1989a),(1989b), Scotchmer(1989a),(1989b), Scotchmer and Slemrod (1989), and Beck et. al. (1990),(1991).) All these studies are based on a single period scenario in which a taxpayer may choose to hire a tax practitioner to reduce or eliminate uncertainty surrounding his taxable income. Typically, in these models, penalties are imposed by the taxing authority when the tax enforcement agent detects a taxpayer who underreports his taxable income. Tax rates and taxpayer's risk attitude also vary in these models so that sensitivity analysis can be performed on the models' results.

The literature generally ascribes a signaling effect to practitioner prepared returns that both the tax enforcement agent and taxpayers find valuable. If the tax reporting system allows for identification of those tax returns that are prepared by practitioners, such as a mandatory signature of the paid practitioner, the government will audit practitioner prepared tax returns at a lower rate than returns prepared by the taxpayers themselves. Under such an extreme scenario, when the practitioners have perfect knowledge of the tax law, practitioner prepared returns should never be audited.

We believe, and we intend to show, that these models, which attribute the benefits that a taxpayer gains by using a tax practitioner to their signature, are inconsistent and fail to capture the reality. It is not at all clear that in reality, practitioner-prepared returns are audited less frequently than self-prepared returns. Yet, taxpayers continue to hire tax practitioners.

Taxpayers may hire practitioners to prepare their returns for a variety of reasons, all of which are related to the ambiguity and complexity of the tax law. These include lack of time or expertise to prepare their own returns, 
morality reasons, such as the belief that a tax practitioner possesses the knowledge to compute the lowest "legal" tax liability (Hite (1988)), or collaborative reasons in which taxpayers believe that tax practitioners are more expert at taking aggressive positions on the interpretation of the tax law than they are themselves (Klepper and Nagin (1989)). In addition, some taxpayers may find that preparing their own tax returns is too onerous a task.

The fact that tax practitioners take aggressive tax return positions is well documented in the literature (Ayres, et. al. (1989), McGill (1988), Milliron (1988)). This may help explain why the IRS's audit rate for practitioner-prepared returns may be the same as for the self-prepared ones. Adding to the above observations the finding that, in practice, penalties, as prescribed by law for underreporting taxable income, are not often imposed (Graetz and Wilde (1985)), it seems that the analytical research in the literature may have failed to keep pace with findings that have emerged from empirical data.

The main thesis underlying this study is that taxpayers' actions may not convey a signal to the tax enforcement agent such that the latter can set different detection rates to different taxpayers, unless they have been previously audited. If taxpayers' actions did convey a signal to the tax enforcement agent, it would eventually lead to a 'corner solution' where all taxpayers would take the same action. This self-revealing unrealistic scenario is not a sustainable solution since all taxpayers would eventually use the service of tax practitioners whose fees are going to be a linear function of the detection rate and penalty for understated income set by the tax enforcement agent. In reality, the presence of a practitioner's signature on a tax return may not signal that the taxing authorities should audit these returns at a lower rate than self-prepared returns. In fact, there is a reason to believe that practitioners take fairly aggressive positions on ambiguous tax issues.

The paper will show that in a single-period framework in which tax practitioners sign tax returns, this leads to a "corner solution" in which all taxpayers will eventually use tax practitioners. We demonstrate, however, that if taxpayers use practitioners who do not sign their tax returns, we are able to obtain the same exact initial solution as in the case in which they sign the returns. In the absence of a practitioner's signature, no signal is conveyed to the tax enforcement agent, and therefore, the solution is sustainable. This finding leads us to the conclusion that the value of these services does not stem from a practitioner's signature; that is, practitioners are not necessarily hired for the value of their signature. Moreover, in reality, practitioners do sign some taxpayers' returns, an observation that leads us to believe that a single-period model does not capture the true variables that explain this puzzle.

The intuition of the above finding is as follows: In a single-period framework, a taxpayer's decision to hire a practitioner is based on two variables - the practitioner's fee, which is known to the tax enforcement agent, and the risk attitude of the taxpayers that can be inferred by the tax enforcement agent if the taxpayers use practitioners who sign the tax returns. In the multi-period framework, the decision of the taxpayer to hire a practitioner is based on an additional variable, which is the change in the likelihood of an audit. Unless a taxpayer has been previously audited, there is no mechanism that will enable the tax enforcement agent to obtain any clue about taxpayers' risk attitude. A multi-period model, however, will be the topic of future research.

This paper is organized as follows: Section II will introduce framework of the basic model and its assumptions and in Section III will introduce the single period framework.

\section{THE BASIC MODEL}

The model assumes a simple competitive economy with three types of agents: taxpayers, who are similar to each other except in risk attitude and level of income, tax practitioners and the tax enforcement agents. The taxpayer is risk averse and unsure of whether a particular expense is tax deductible, or whether a particular item of income is taxable. The taxpayer can either file his tax return on his own or hire a tax practitioner.

The taxpayer views tax practitioners as having expertise in the tax law or its interpretation by the tax enforcement agent. The practitioners and the tax enforcement agents are assumed to have perfect knowledge and uniform understanding of the tax law. Assuming, instead, variability in the levels of knowledge of the tax code will reinforce the results of this model, since if the conclusions of the model are correct for the case of perfect knowledge, they are also correct for the case in which practitioners vary in their level of knowledge. 
It is further assumed that the tax code is unchanged over the entire horizon of the tax planning.

Each taxpayer realizes a level of income before reporting his taxable income. While reporting his taxable income, he may decide to hire a tax practitioner or to report his taxable income on his own. The tax payer, being risk averse and uncertain about his taxable income, faces an ex-ante choice of taking one of the following three actions:

- Report on his own a high level of taxable income, $Y_{h}$, while his taxable income in a case of an audit can be either $Y_{h}$ or the lower taxable income, $Y_{l}$.

- $\quad$ Report on his own a low level of taxable income, $Y_{l}$, while his taxable income in a case of an audit can be either $Y_{l}$, or the higher taxable income, $Y_{h}$.

- $\quad$ Hire a tax practitioner who, based on his perfect knowledge of the tax law will advise the tax payer of his 'true income', $Y_{l}$ or $Y_{h}$, and subsequently the taxpayer will file tax return showing the taxable income calculated by the tax practitioner.

Ex-ante, without any prior information, the taxpayer believes that:

- A detection rate, $\mathrm{q}$, is set by the taxing authorities, and therefore the probability that he would be audited in absence of any revealing signal is q.

- $\quad$ No other taxpayer will take a self-serving action that may identify his own characteristics, that is, his risk attitude. Alternatively, if there exists a signal that a taxpayer can send to the tax enforcement agent in order to reduce the likelihood of being audited, then he believes that all taxpayers will follow through with the same signal.

- If he is audited, the probability that the tax enforcement agent will determine that his 'true' taxable income is $Y_{h}$ is $\mathrm{p}$, and (1-p), that it is $Y_{l}$.

The taxpayer is assumed to be rational in the sense that in absence of new information his actions are consistent, that is; if he decides to take a particular action at the present moment and the circumstances do not change, he will take the same action in the future.

The tax practitioner charges a fee for his services. The fee cannot exceed the penalty imposed by the tax authorities on tax liabilities that have been underpaid. The fee is assumed to be net of bookkeeping services, which must be incurred, irrespective if the taxpayer hires a practitioner or files on his own. Thus, the fee has a lower bound of zero and an upper bound of the tax penalty.

The fee can be charged in accordance with either of the following two rules:

- $\quad$ Flat fee or proportional fee to the taxpayer's taxable income.

- If the practitioner had full knowledge of taxpayers' risk preferences, a fee, proportional to the value of the additional utility, if any, that the taxpayer obtains by using a practitioner as opposed to filing the return on his own.

This paper will demonstrate that these two pricing policies will lead to very different results.

The tax enforcement agent, upon an audit of a tax return, wishes to collect the exact amount as prescribed by the tax code. A-priori the agent has no information about the taxpayer, nor can he infer any from the level of income reported, since every taxpayer has his own 'high' and 'low' levels of income.

In absence of any taxpayer-specific signals, the tax enforcement agent conducts audits through a random mechanism of selection, whereas the detection rate, $q$, is publicly known. The agent wishes to receive signals about 
taxpayers' characteristics, so that these signals will enable him to conduct audits of taxpayers who are more likely to understate incomes.

The tax code in the model is very simple. There is only an income tax with progressive rates, $\tau$, that is $\tau_{h}>\tau_{l}$. If the tax enforcement agent finds that the taxpayer understates his taxable income, then he imposes a penalty at a rate of $\pi$ of the deficient tax payment. Thus, the total tax due is $\square \square \square+\pi \square$ of the deficient tax liability.

We believe that the assumptions underlying the model of this paper are fairly realistic, except the assumption that taxpayers do not deliberately evade taxes. This assumption implies that if a taxpayer decides to hire a practitioner and subsequently the taxpayer files a tax return on his own, he would report exactly the finding of the tax practitioner. Thus, there will be a group of the least risk averse taxpayers who will not hire tax practitioners even if their fee is nil. This conclusion, being perhaps somewhat unrealistic, is used only to compare groups of taxpayers. It is, however, not a crucial one for the general thesis of this paper.

Though tax evasion as a deliberate action is assumed away, the model does not rule out that tax evasion is a potential rational action. Thus, we do not rule out that the expected value of one dollar of income which is deliberately not reported on the tax return, $(1-q \tau(1+\pi))$, exceed the after-tax value of this dollar $(1-\tau$ that is, $q(1+\pi)<1$. If the latter relationship does not hold, no taxpayer is ever going to knowingly evade taxes. Moreover, if we ruled out a rational tax evasion, it could bias the results towards using tax practitioners for reasons which lie outside the scope of this paper. Assuming away deliberate tax evasion implies that a taxpayer who hires a practitioner will report the income calculated by the practitioner, since the expected benefit of tax evasion, $[(1-q \tau(1+\pi))]-[(1-\tau)]=t(1-q(1+\pi)$, is smaller than the risk premium for tax evasion for all taxpayers. As it will be shown, this assumption implies that some taxpayers may not hire a practitioner even if his fee is nil (see Proposition 1).

Finally, in order to avoid signaling manipulations in the financial markets, the following, possibly dominant, strategy is assumed away. If the taxpayer is a publicly traded corporation, the taxpayer may always elect to report $Y_{h}$ and may benefit from reporting $Y_{h}$ in two ways. First, he may manage to 'fool' the financial markets by making them believe that $Y_{h}$ is the true income, and second, if he reports $Y_{h}$ when $Y_{l}$ is the true income, and he is audited, he gains through tax refunds or credit.

\section{SINGLE PERIOD ANALYSIS}

The purpose of this section is to show that the same results, previously derived elsewhere, can be obtained under the assumptions of our model. This section will show, however, that in a single-period scenario, in which practitioners sign the tax returns, the solution is not sustainable since taxpayers' actions are self revealing.

If the taxpayer decides to self-report $Y_{h}$, his expected after-tax income, $E(Y / h)$ is:

$$
\begin{aligned}
E(Y / h)= & (1-p)\left(Y-Y_{h} \tau_{h}\right) \\
& +(1-p) q\left(Y-Y_{l} \tau_{l}\right) \\
& +p q\left(Y-Y_{h} \tau_{h}\right) \\
& =Y-Y_{h} \tau_{h}+q \Delta(1-p)
\end{aligned}
$$

He reports $Y_{h}$ and he is not audited.

He reports $Y_{h}$ and he is audited and $Y_{l}$ is found to be the true income.

He reports $Y_{h}$ and an audit confirms $Y_{h}$.

where $\Delta=Y_{h} \tau_{h}-Y_{l} \tau_{l}$ is the difference in tax liabilities when $Y_{h}$ or $Y_{l}$ are reported.

If the taxpayer chooses, however, to self-report $Y_{l}$, his expected after-tax income, $E(Y / l)$ is: 


$$
\begin{aligned}
E(Y / l)= & (1-q)\left(Y-Y_{l} \tau_{l}\right) \\
& +p q\left(Y-Y_{h} \tau_{h}\right)-p q \pi \Delta \\
& +q(1-p)\left(Y-Y_{l} \tau_{l}\right) \\
& =Y-Y_{l} \tau_{l}-p q \Delta(1+\pi)
\end{aligned}
$$

He reports $Y_{l}$ and he is not audited.

He reports $Y_{l}$ and he is audited and $Y_{h}$ is found to be the true income. $^{l}$

He reports $Y_{l}$ and an audit confirms $Y_{l}$.

The taxpayer considers hiring a tax practitioner. The tax practitioner will calculate the taxpayer's true income. Thus, his expected after-tax-income, given that he is going to hire a tax practitioner, $E(Y / p)$ is:

$\mathrm{E}(\mathrm{Y} / \mathrm{p})=p\left(Y-Y_{h} \tau_{h}\right)+(1-p)\left(Y-Y_{l} \tau_{l}\right)=Y-Y_{l} \tau_{l}-p \Delta$

Rearranging (1) and (2) and inserting (3) yields:

$E(Y / h)=E(Y / p)-(1-p)(1-q) \Delta$

$E(Y / l)=E(Y / p)+p(1-q \pi-q) \Delta$

\section{Proposition 1}

If $q(1+\pi)<1$, and the practitioner's fee is nil, then, $E(Y / l)>E(Y / p)>E(Y / h)$.

If deliberate tax evasion is ruled out by assumption, some taxpayers may rationally report $Y_{l}$ on their own, even if practitioners have charged no fee for their services.

If $q(1+\pi)>1$ and the practitioner's fee were nil, all taxpayers would hire tax practitioners.

\section{Proof}

The proposition states that the expected income after-tax when the taxpayer reports on his own $Y_{l}$ is higher than the expected after-tax income if he hires a tax practitioner. The latter is higher than the expected after-tax income if he reports on his own $Y_{h}$.

Note that the condition $q(1+\pi)<1$ is the same as the one stating that tax evasion, as a rational action, may not be ruled out. Additionally, we assume that even if tax evasion may not be ruled out, no taxpayer deliberately evades taxes.

The proof follows immediately from Equation (4a) and (4b) and from the conditions, $1>q(1+\pi), p<1$ and $q<1$.

An immediate implication is that even if practitioners' fee is zero some taxpayers may choose to report $Y_{l}$ on their own. This is true since if a taxpayer hires a practitioner he would have to report $Y_{h}$ if this is what the practitioner calculated as the taxable income. If we allowed deliberate tax evasion, the least risk averse taxpayers may elect to self-report $Y_{l}$ despite of the practitioner's finding.

\footnotetext{
1 The taxpayer may challenge the determination of the tax enforcement agent in court. This possibility will not alter the results
} but may increase somewhat the value of $\pi$. 
Only if tax evasion becomes rationally prohibitive due to very high penalties or high probability of detection, then all taxpayers will rationally use practitioners, if their fee is nil.

\section{QED}

The above conclusions hold whether or not practitioners sign the tax returns. Thus, the fee that practitioners charge the taxpayers is for reviewing their tax returns and not for signing the returns. We consider two forms of practitioners' fee; first is a flat fee across all taxpayers, or a proportional fee to the level of taxable income. The second type is the 'economic fee' which is the amount a specific taxpayer is willing to pay based on the total benefits derived from using tax practitioners.

We proceed now to show the solution of the single period scenario where taxpayers' decision is solely driven by their risk attitude. The following result is needed first.

\section{Lemma 1}

If a taxpayer possesses a strictly concave utility function, $U(Y)$, then,

$E U(Y / h)=E U(Y / p)-\left[(1-p)(1-q)\left\{U\left(\Delta_{l}\right)-U\left(\Delta_{l}-\Delta\right)\right\}\right]$

$E U(Y / l)=E U(Y / p)+\left[p\left\{U\left(\Delta_{h}+\Delta\right)-U\left(\Delta_{h}\right)\right\}-p q\left\{Y\left(\Delta_{h}-\Delta \pi\right)\right\}\right]$

where $\Delta_{h}=Y-Y_{h} \tau_{h}$ and $\Delta_{l}=Y-Y_{l} \tau_{l}$.

Proof is given in Appendix A. practitioner.

Proposition 2 derives the single-period solution with respect to the motivation of taxpayers to hire a tax

\section{Proposition 2}

Assuming that there is no deliberate tax evasion, and given a set of possible taxable incomes that a taxpayer contemplates, one of which is the true taxable income, then, there is a sufficiently risk averse taxpayer, who will hire a tax practitioner, while any other less risk averse taxpayer will file the tax return on his own without consulting a tax practitioner and will always report the lowest income in this set. The latter is true even if tax practitioners charge no fee for their services.

Proof

Assume a set of taxable incomes comprised of 'high' and 'low' incomes. A risk neutral taxpayer always file on his own and report the low income, $Y_{l}$, as opposed to the high income, $Y_{h}$. This is true since for a risk neutral taxpayer, possessing a linear utility function, $U(Y)$,

$U\left(\Delta_{l}\right)-U\left(\Delta_{l}-\Delta\right)=U\left(\Delta_{h}+\Delta\right)-U\left(\Delta_{h}\right)=U(\Delta)$

Then, from Lemma 1,

$E U(Y / l)-E U(y / p)=p\{U(\Delta)\}-p q\{U(\Delta \pi)\}>0$

and 
thus,

$E U(Y / l)>E U(Y / p)>E U(Y / h)$.

This means that no risk neutral taxpayer has an incentive to hire a tax practitioner. Putting it differently; the value of a tax practitioner's services to a risk averse taxpayer are nil. Even if a tax practitioner charged no fee he would still not hire him, since if the tax practitioner finds that his true income is $Y_{h}$, reporting $Y_{l}$ will be considered as a deliberate tax evasion which is ruled out by our model.

On the other hand, since for a risk averse tax payer,

$U\left(\Delta_{l}\right)-U\left(\Delta_{l}-\Delta\right)>U\left(\Delta_{h}+\Delta\right)-U\left(\Delta_{h}\right)$

Then, from Lemma 1, it is still true that $\mathrm{EU}(Y / p)>E U(Y / h)$, but for a sufficiently risk averse taxpayers it may be true that,

$E U(Y / p)>E U(Y / h)>E U(Y / l)$

Equation (11) implies that this taxpayer may hire a tax practitioner, depending obviously on the practitioner's fee. Less risk averse taxpayers may find the fee prohibitive and file their tax return on their own.

\section{QED}

The above conclusion is intuitive and is already known in the case in which the tax practitioner signs the return. It is also true even if the tax practitioner does not sign the return; that is, the benefits that a taxpayer derives from the tax practitioner's services do not necessarily stem from the value of his signature.

A tax practitioner who maximizes his fees and has knowledge of his client's risk preferences, will charge the client the maximum amount the taxpayer is willing to pay, that is, the "economic fee." This amount is given indirectly by Lemma 1. Tax practitioners, however, are unable to charge a "discriminating" fee derived from their client's risk attitude. Thus, the more realistic case is when practitioners charge a fixed or proportional income fee. This fee is bounded from above by the amount $\pi \Delta$, since no taxpayer would engage the practitioner's services if the fee were to exceed the difference between the amount of taxes due for the taxable incomes, $Y_{l}$ and $Y_{h}$. In fact, the upper bound on the practitioner's fee could be shown to be even lower than $\pi \Delta$. The reason is as follows:

If practitioner's fee is between zero and $E(Y / p)-E(Y / h)$, some taxpayer will self-report $Y_{l}$, but no one will self-report $Y_{h}$. This is true since the least risky outcome, $E(Y / p)$, less the practitioner's fee, is still higher than $E(Y / h)$. If the fee exceeds $E(Y / p)-E(Y / h)$, some taxpayers who might otherwise use a practitioner would self-report $Y_{h}$. Others, who are the least risk averse among taxpayers and who might otherwise use practitioners, might selfreport $Y_{l}$. In this case, no taxpayers would use a tax practitioner.

Based on Proposition 2, taxpayers will sort themselves into three groups. The first group will report $Y_{l}$, regardless of the amount of the practitioner's fee. The second group will hire a practitioner, but since the fee is higher than the benefit the taxpayer can gain, the taxpayer will file the return on his own. The third group will find it beneficial to hire a practitioner and report the income that he calculates. This conclusion is true whether or not practitioners sign the return, and it is true for both types of practitioner's fees (see Table 1). 
Table 1: Various Scenarios of Practitioner's Fee and Different Taxpayers' Risk Attitude

Though a tax practitioner, if hired, does not sign the tax return, the solution is the same as in a world where he does sign the return.

\begin{tabular}{|c|c|c|c|}
\hline $\begin{array}{l}\text { Scale of risk } \\
\text { aversion }\end{array}$ & \multicolumn{2}{|l|}{ low risk aversion } & high risk aversion \\
\hline Decision & $\begin{array}{l}\text { Self report low } \\
\text { income irrespective } \\
\text { of practioner's fee }\end{array}$ & $\begin{array}{l}\text { Self report low income } \\
\text { since practioner's fee } \\
\text { exceeds the benefits }\end{array}$ & $\begin{array}{l}\text { Use practioner since } \\
\text { benefits exceed fee }\end{array}$ \\
\hline $\begin{array}{l}\text { Decision with } \\
\text { 'economic' fee } \\
\text { or zero fee }\end{array}$ & $\begin{array}{l}\text { Self report low } \\
\text { income irrespective } \\
\text { of practioner's fee }\end{array}$ & $\begin{array}{l}\text { Use practioner since } \\
\text { than the economic fee }\end{array}$ & benefits are not less than \\
\hline $\begin{array}{l}\text { Decision with } \\
\text { flat fee less than } \\
E(Y / p)-E(Y / h)\end{array}$ & $\begin{array}{l}\text { Self report low } \\
\text { income irrespective } \\
\text { of practioner's fee }\end{array}$ & $\begin{array}{l}\text { Self report low } \\
\text { income } \\
\text { since fee exceeds the } \\
\text { risk adjusted }\end{array}$ & $\begin{array}{l}\text { Use practitioner since } \\
\text { risk adjuested outcome } \\
\text { of self reporting } \mathrm{Y} 1 \text { is } \\
\text { smaller than }[\mathrm{E}(\mathrm{Y} / \mathrm{p})-\text { fee }]\end{array}$ \\
\hline $\begin{array}{l}\text { Decision with } \\
\text { flat fee less than } \\
\mathrm{E}(\mathrm{Y} / \mathrm{l})-\mathrm{E}(\mathrm{Y} / \mathrm{p}) \\
\text { but more than } \\
\mathrm{E}(\mathrm{Y} / \mathrm{p})-\mathrm{E}(\mathrm{Y} / \mathrm{h})\end{array}$ & $\begin{array}{l}\text { Self report low } \\
\text { income irrespective } \\
\text { of practioner's fee }\end{array}$ & $\begin{array}{l}\text { Self report low income } \\
\text { since the risk adjusted } \\
\mathrm{E}(\mathrm{Y} / \mathrm{l})-\mathrm{E}(\mathrm{Y} / \mathrm{h}) \text { is still } \\
\text { positive while } \\
\mathrm{E}(\mathrm{Y} / \mathrm{p})-\mathrm{E}(\mathrm{Y} / \mathrm{h})<0\end{array}$ & $\begin{array}{l}\text { Self report high } \\
\text { Income since the } \\
\text { risk adjusted } \\
\quad \mathrm{E}(\mathrm{Y} / \mathrm{l})-\mathrm{E}(\mathrm{Y} / \mathrm{h}) \text { is } \\
\text { negative as well as } \\
\mathrm{E}(\mathrm{Y} / \mathrm{p})-\mathrm{E}(\mathrm{Y} / \mathrm{h})\end{array}$ \\
\hline
\end{tabular}

Though the solution shown in Table 1 is the same whether or not the tax practitioner signs the return, this study refutes the notion that tax practitioners are hired for the "value" associated with their signatures. There are two reasons for this conclusion. First, if the same taxpayers hire a practitioner whether or not he signs the return, these taxpayers engage his services for reasons other than the "value" of his signature. More importantly, the solution in a world in which the practitioner does sign the return and the taxpayers hire him solely for the value of this signature is not sustainable, since eventually no taxpayer will file a tax return on his own. This is the case, since the taxpayer sends a valuable signal to the tax enforcement agent, who will increase the detection rate for taxpayers who report on their own and decrease the detection rate for those whose tax returns are signed by practitioners. The increase in the detection rate will drive some self-reporting taxpayers to use practitioners. This in turn, will further increase the detection rate, since the group of taxpayers who will be targeted by the tax enforcement agent is smaller. The smaller the number of self- reporting taxpayers, the higher the probability that they will be audited, in turn reducing the number of self-reporting taxpayers even further, until no taxpayer files on his own. This "corner solution," however, is not compatible with the reality, nor with this model, that assumes that the actions taken by the taxpayers are not self-revealing.

We believe, therefore, that a multi-period scenario, in which the motivation to hire practitioners does not stem from the "value" of their signature, is more applicable. 


\section{CONCLUSION}

In a single-period framework, the taxpayer's decision to hire a practitioner is linked to two variables - the practitioner's fee that is known to the tax enforcement agent, and the risk attitude of the taxpayer that can be inferred by the tax enforcement agent if the taxpayer employs a practitioner who signs the tax returns. It appears that by keeping the assumptions used to derive this model, the model can be extended to a multi-period framework where the taxpayer's risk attitude can be inferred by his inter-temporal actions. This, however, will be left for future research.

\section{AUTHOR INFORMATION}

Dr. Vassilios N. Gargalas is currently assistant Professor of Finance at Herbert H. Lehman College in New York. He has previously served on the faculties of New York University, Fordham University, University of Bridgeport, Western Connecticut State University, Touro College, as well as other institution in the United Stated and Europe. Dr. Gargalas teaches courses in corporate finance, investments, international finance, and financial institutions. His primary areas of research and publication have been related to corporate finance and financial institutions. Dr. Gargalas received his B.Sc. from Athens University of Economics, his M.Phil. from New York University, and was awarded his Ph.D. in Finance from New York University. He has consulted with a number of financial institutions including Merrill Lynch, Deutsche Bank, Aetolian Capital, etc.

\section{REFERENCES}

1. Alm, J. 1988. Uncertain tax policies, individual behavior, and welfare. American Economic Review (March):237-45.

2. Ayres, F., B. Jackson and P. Hite. 1989. The economic benefit of regulation: evidence from professional tax preparers. The Accounting Review 65(April):300-12.

3. Beck, P., J. Davis and W. Jung. 1991. Experimental evidence of taxpayer reporting under uncertainty. The Accounting Review 66(July):535-58.

4. Beck, P., J. Davis and W. Jung. 1990. The role of tax practitioners in tax reporting: a signaling game. Unpublished manuscript (July) .

5. Beck, P. and W. Jung. 1989a. Taxpayers' reporting decisions and auditing under information asymmetry. The Accounting Review 64(July):468-87.

6. Beck, P. and W. Jung. 1989b. Taxpayer compliance under uncertainty. Journal of Accounting and Public Policy 8(Spring):1-27.

7. Graetz. M. and L. Wilde. 1985. The Economics of tax compliance: fact and fantasy. National Tax Journal 38(September):345-63 .

8. Hite, P. 1988. The effect of peer reporting behavior on taxpayer compliance. The Journal of the American Taxation Association 9(Spring):47-64.

9. Klepper, S. and D. Nagin. 1989. The role of tax practitioners in tax compliance. Policy Sciences 22(May):167-94.

10. McGill, G. 1988. The CPA's role in income tax compliance: an empirical study of variability in recommending aggressive tax positions. PhD. dissertation, Texas Tech University.

11. Milliron, V. 1988. A conceptual model of factors influencing tax preparers' aggressiveness. In S. Moriarty and J. Collins eds. Contemporary Tax Research. University of Oklahoma:1-15.

12. Scotchmer, S. 1989a. Who profits from taxpayer confusion? Economics Letters 29(February):49-55.

13. Scotchmer, S. 1989b. The effect of tax advisors on tax compliance. In Taxpayer Compliance: Social Science PersDectives, Volume 2 edited by J. Roth and J. Scholz. University of Pennsylvania Press: 156-81.

14. Scotchmer, S. and J. Slemrod. 1989. Randomness in tax enforcement. Journal of Public Economics 38(February):17-32.

15. Shavell, S. 1988, Legal advice about contemplated acts: the decision to obtain advice, its social desirability, and protection of confidentiality. Journal of Legal Studies 17(January): 123-50. 


\section{APPENDIX A}

$$
\begin{aligned}
E U(Y / h) & =p U\left(Y_{h}\right)+(1-p)\left[q U\left(Y_{l}\right)+(1-q) U\left(Y_{l}-\Delta\right)\right] \\
& =p U\left(Y_{h}\right)+(1-p)\left[q U\left(Y_{l}\right)+(1-q) U\left(Y_{l}-\Delta\right)\right]+(1-p) U\left(Y_{l}\right)-(1-p) U\left(Y_{l}\right)
\end{aligned}
$$

Since the low income, $Y_{l}$, means $Y-Y_{l} \tau_{l}=\Delta_{l}$ :

$E U(Y / h)=E U(Y / p)-\left[(1-p)(1-q)\left\{U\left(\Delta_{l}\right)-U\left(\Delta_{l}-\Delta\right)\right\}\right]$

Similarly,

$$
\begin{aligned}
E U(Y / l)= & (1-p) U\left(Y_{l}\right)+p q U\left(Y_{h}-\pi \Delta\right)+P(1-q) U\left(Y_{l}\right) \\
& =(1-p) U\left(Y_{l}\right)+p q U\left(Y_{h}-\pi \Delta\right)+P(1-q) U\left(Y_{h}+\Delta\right)+p U\left(Y_{h}\right)-p U\left(Y_{h}\right)
\end{aligned}
$$

Since the high income, $Y_{h}$, means $Y-Y_{h} \tau_{h}=\Delta_{h}$ :

$E U(Y / l)=E U(Y / p)+\left[p\left\{U\left(\Delta_{h}+\Delta\right)-U\left(\Delta_{h}\right)\right\}-p q\left\{Y\left(\Delta_{h}-\Delta \pi\right)\right\}\right]$

QED 